\title{
KAEDAH VISUAL DAN PENGGOLONGAN MAKNA AKHIRAN -an $\{$-an\}
}

\section{(Visual Methods and Classification of the Meaning of the Suffix -an $\{-a n\})$}

Norulhudda Adnan

myan2021kok@gmail.com

Kementerian Pendidikan Brunei Darussalam.

SatoHirobumi@Rahmat*

satoumbangkok@um.edu.my

Fakulti Bahasa dan Linguistik, Universiti Malaya, Malaysia.

Fakulti Kemanusiaan dan Sains Sosial, Universiti Yala Rajabhat, Thailand.

Pengarang koresponden (Corresponding author): *

Sila rujuk: Nurulhuda Adnan \& Sato Hirobumi@Rahmat. (2022). Kaedah visual dan penggolongan makna akhiran -an \{-an\}. Melayu: Jurnal Antarabangsa Dunia Melayu, 15(1), 137-160. http://doi.org. 10.37052/jm.15(1)no7

\begin{tabular}{|lllll}
\hline $\begin{array}{l}\text { Peroleh: } \\
\text { Received: }\end{array}$ 8/12/2021 & $\begin{array}{l}\text { Semakan: } \\
\text { Revised }\end{array}$ & 24/12/2021 & $\begin{array}{l}\text { Terima: } \\
\text { Accepted: 29/12/2021 }\end{array}$ & $\begin{array}{l}\text { Terbit dalam talian: } \\
\text { Published online: }\end{array}$
\end{tabular}

\begin{abstract}
Abstrak
Kajian pedagogi dalam morfologi bahasa Melayu telah lama dijalankan sejak abad ke-19. Dalam hal ini, Boer (1951) dalam buku tatabahasanya mengemaskan penggolongan makna akhiran -an \{-an\} kepada tiga golongan besar dalam bahasa Melayu. Sejak tahun 1980-an hasil analisis makna akhiran -an dikemukakan secara terperinci di Indonesia dan di Malaysia. Penulis membandingkan tiga buah buku tatabahasa tokoh bahasa Melayu, iaitu Asmah (2009), Harimurti (1996), dan Nik Safiah et al. (2010). Akan tetapi, hasil kajian ini mendapati pelbagai makna akhiran berkenaan tidak dikaitkan antara satu sama lain. Artikel ini menggunakan penyusunan semula logik terhadap penggolongan makna dengan memperkenalkan
\end{abstract}

(C) Dewan Bahasa dan Pustaka. 2022. This work is licensed under the term of the Creative Commons Attribution (CC BY) (http://creative commons.org/licenses/by/4.0/)

ISSN 1675-6460 e-ISSN 2682-8049 
empat penggolongan makna akhiran -an \{-an\} bersama-sama dengan idea matematik asas, himpunan dan tindanan, untuk mengelaskannya, iaitu I. "satuan himpunan", II. "keserupaan", III. "sesuatu yang berkaitan dengan proses perbuatan", dan IV. "pengaruh bahasa sukuan di Indonesia". Dengan penggolongan ini, hubungan antara pelbagai makna akhiran -an $\{-a n\}$ dapat diperjelas dengan mudah. Kaedah yang diusahakan oleh pengkaji asing ini merupakan hasil pembelajaran pelajar asing yang belajar bahasa Melayu untuk meringankan beban hafalan melalui kamus dan tatabahasa buku teks.

Kata kunci: Akhiran -an $\{$-an\}, kaedah visual, keserupaan, penggolongan makna, proses perbuatan, satuan himpunan makna

\begin{abstract}
Pedagogical studies in the morphology of Malay language have long been conducted since the 19th century. In this regard, Boer (1951), in his grammatical work, has summarized the classification of the meaning of the suffix -an $\{$-an\} into three major groups. However, this work is hardly noticed by local researchers. Since the 1980s, the results of the analyses of the meaning of the suffix concerned have been presented in detail in Indonesia and Malaysia. The author has compared three Malay-language works, namely Asmah (2009), Harimurti (1996), and Nik Safiah et al. (2010). However, the various meanings of the suffixes concerned are not related to each other. This article used a logical rearrangement of the classification of meaning and introduces four classifications of the meaning of the suffix -an \{-an\} along with basic mathematical ideas as their auxiliaries, namely: I. "set unit"; II. "similarity"; III. "something related with the process of action", and; $I V$. "the influence of tribal languages in Indonesia". With this classification, the relationship between the various meanings of the suffix -an \{-an\} could be clarified easily. The method used by this foreign researcher is the result of foreign students who are learning Malay language in order to ease the burden of memorization through dictionary and textbook grammar.
\end{abstract}

Keywords: Classification of the meaning, process of action, similarity, suffix -an $\{$-an\}, visual methods, unit of set of the meanings

\title{
PENDAHULUAN
}

Penutur jati bahasa Melayu, pada dasarnya, mempelajari jenis dan makna imbuhan bahasa Melayu secara sedar, melalui pendidikan sekolah. Sebaliknya, pelajar asing yang rata-rata terdiri daripada kalangan mahasiswa mendepaninya, mulai awal pembelajaran bahasa ini. Dalam hal ini, baik bagi penutur jati mahupun pelajar asing, 
pengimbuhan akhiran -an $\{-$ an $\}$ dikatakan paling mudah dipelajari kerana imbuhan ini tidak mengalami sebarang perubahan bentuk dari segi morfologi. Maksudnya, akhiran -an $\{$-an $\}$ ini mempunyai satu morf/-an/ sahaja. Namun begitu, akhiran ini ternyata mempunyai makna kata terbitannya yang sukar disepadukan dalam satu makna yang besar. Linguistik historis Melayu yang bermula pada abad ke-19 belum dapat dipastikan sama ada akhiran yang dilambangkan dengan satu jenis -an \{-an\} /-an/ pada zaman kini dikembangkan daripada satu akar yang sama atau tidak. Hal yang sama diperkatakan dalam Sato (2020) melalui artikel "Lakaran Serentetan Makna Awalan me(N)- dan te(R)- dalam Bahasa Melayu". Wouk (1980), Chung (2011), dan Sato \& Manavavee (2020) yang cuba mencari sifat asas yang terdapat dalam analisis awalan te(R)- dalam bahasa Melayu turut memperkatakan perkara yang sama. Hal ini disebabkan kebanyakan pelajar asing belajar bahasa ini melalui kamus dan tatabahasa sahaja. Kaedah analisis imbuhan yang diusahakan oleh pelajar asing tersebut akan dapat dimanfaatkan oleh pelajar Malaysia.

Berdasarkan andaian bahawa akhiran -an $\{$-an $\}$ berkembang daripada satu makna asas, artikel ini menyusun semula hubungan antara pelbagai makna akhiran berkenaan yang disediakan oleh pakar bahasa Melayu, untuk digolongkan kepada tiga golongan besar beserta informasi bahasa sukuan, berdasarkan idea himpunan untuk meningkatkan keberkesanan pemahaman pelajar dari segi pedagogi. Kaedah visual dan informasi akhiran -an $\{-a n\}$ yang diterapkan dalam artikel ini sudah mendapat sambutan yang baik dalam kalangan guru sekolah Negara Brunei Darussalam sejak dibentangkan pada seminar bahasa, Dewan Bahasa dan Pustaka, Brunei Darussalam (tahun 2012). Hal ini bermakna bahawa penemuan yang dibentangkan merupakan kaedah pedagogi yang telah diamalkan sekian lama.

\section{PERMASALAHAN KAJIAN}

Menurut Abdullah Hassan (1986:117), pembentukan kata dengan pengimbuhan akhiran -an $\{-a n\}$ menerbitkan kata nama dari segi penggolongan kata. Namun begitu, ternyata akhiran -an $\{$-an $\}$ juga dapat menerbitkan golongan kata yang lain seperti kata bilangan, kata adjektif, kata kerja, dan kata adverba melalui pengimbuhan.

Sementara itu, tiga buah karya yang dirujuk secara meluas dalam kalangan guru bahasa Melayu di negara-negara rantau Melayu dipilih sebagai bahan perbandingan tatabahasa dalam artikel ini, iaitu: 
MELAYU: JURNAL ANTARABANGSA DUNIA MELAYU JILID 15 BIL. 1 JANUARI 2022

Jadual 1 Perbezaan tafsiran dalam buku tatabahasa.

\begin{tabular}{|c|c|c|c|}
\hline Nama karya & NMM & TD & PKDBI \\
\hline Makna akhiran -an & Sama dengan & $\begin{array}{c}\text { Bidang yang luas } \\
\text { atau kawasan }\end{array}$ & Lokatif \\
\hline Contoh kata terbitan & . jalan + -an & . sisi + -an & . titi + -an \\
\hline
\end{tabular}

(a) Asmah Haji Omar. (2009). Nahu Melayu Mutakhir (NMM)

(b) Harimurti Kridalaksana. (1996). Pembentukan Kata dalam Bahasa Indonesia (PKDBI)

(c) Nik Safiah Karim et al. (2010). Tatabahasa Dewan (TD)

Perbandingan ketiga-tiga buah karya yang dikarang oleh tokoh bahasa Melayu ini ternyata memperlihatkan perbezaan pandangan pengarang masing-masing terhadap tafsiran makna akhiran -an \{-an\}, iaitu NMM (2009) menyenaraikan 16 penggolongan, PKDBI (1996) menyenaraikan 31 penggolongan, tetapi TD (2010) menyenaraikan sembilan penggolongan sahaja. Dalam hal ini timbul satu soalan sejauh manakah dapat dilihat kepentingan kajian yang mempelbagaikan makna akhiran -an $\{-a n\}$ secara terperinci itu tidak memperlihatkan hubungan antaranya? Sekurang-kurangnya ketidakwujudan hubungan makna akhiran -an itu membebankan pelajar dari sudut pedagogi. Perbezaan tafsiran makna seperti Jadual 1 pada pendangan penulis menyukarkan pemahaman para pelajar.

Salah satu makna akhiran -an $\{$-an $\}$ ini jelas membawa makna "lokatif=tempat" tetapi tafsirannya sudah berbeza-beza antara satu sama lain. Seandainya perincian makna akhiran -an \{-an\} itu dapat digolongkan di bawah satu payung yang besar, hubungan antara perincian makna itu barangkali akan dapat memberikan manfaat kepada pelajar.

Badudu dan Zain menyusun Kamus Umum Bahasa Indonesia (1994) yang memperbaharui Kamus Moderen Bahasa Indonesia (1954). Kamus yang terbaharu ini memperkenalkan kosa kata standard yang terbaharu pada masa itu. Misalnya, kata terbitan berakhiran -an $\{$-an\} yang digunakan di Negara Brunei Darussalam dan Malaysia seperti rusuhan ( $<$ rusuh) dan rawatan ( $<$ rawat) diperkenalkan sebagai kerusuhan (apitan: ke-/-an) dan perawatan (apitan: ke-/-an) dengan makna perbuatan/ proses yang sama dalam kamus bahasa Indonesia tersebut. Oleh hal yang demikian, pemilihan dan analisis kata terbitan berakhiran -an $\{-a n\}$ perlu diberikan perhatian . 


\section{METODOLOGI KAJIAN}

Kajian morfologi ini, seperti analisis dalam tiga buah karya tersebut, tidak menggunakan sebarang teori yang tertentu kerana pertama, teori bahasa dunia Barat yang bersifat fleksi tidak sesuai dengan tatabahasa bahasa Melayu yang bersifat aglutinatif, dan kedua, kaedah yang digunakan dalam artikel ini adalah secara logik, "satuan himpunan" yang mampu menganalisis makna kata terbitan berakhiran -an \{-an\} dalam bahasa Melayu/Indonesia, seperti contoh minuman (sesuatu yang diminum) dan anak-anakan (boneka mainan yang menyerupai anak). Penutur jati tidak akan mempertimbangkan komponen makna semantik dalam penggunaan bahasa sehari-hari seperti yang dicipta oleh sebilangan pakar bahasa. Hal yang serupa dapat dikatakan dalam pemberian makna dalam penyusunan kamus bahasa.

Yang penting, penggolongan makna akhiran ini memerlukan pertukaran sudut pandang secara logik. Kaedah logik yang sedemikian pernah digunakan dalam kajian bahasa Melayu oleh Sato (2007) terhadap analisis ungkapan "Matahari Sepenggalah Tingginya". Beliau tidak menggunakan sebarang teori yang tertentu, melainkan satu teorem matematik yang dicipta oleh Pythagoras pada abad ke-5 sebelum Masihi sahaja yang diterapkan.

Artikel kajian makna akhiran -an $\{$-an $\}$ ini menggunakan idea matematik "himpunan" yang dipelajari sejak sekolah rendah terlebih dahulu, kemudian gambaran himpunan yang dilakarkan dalam hubungan keseluruhan dengan unsur itu ditukar kepada "gambaran pertindihan benda" dan "gambaran tanda panah perbuatan". Semua ini merupakan idea matematik asas yang dikemukakan secara logik. Akhir sekali, "pengaruh bahasa sukuan (bahasa daerah)" dari Indonesia diperkenalkan untuk memberikan kefahaman tentang kata terbitan berakhiran -an. Kaedah visual yang digunakan dalam artikel ini juga akan membantu sebahagian pelajar secara berkesan.

\section{SOROTAN LITERATUR}

Kajian pedagogi terhadap imbuhan bahasa Melayu mulai dijalankan sejak abad ke19, bermula dengan karya Hollander (1882). Karya ini diikuti oleh Wijk (1893), Klinkert (1898), Spat (1900, 1931), Tendeloo (1901), dan Ophuijsen (1915) yang kesemuanya diusahakan dalam bahasa Belanda. Winstedt (1913) merupakan satusatunya karya pedagogi bahasa Melayu yang diusahakan dalam bahasa Inggeris. Karya pengkaji tempatan yang menyusuli karya-karya tersebut ialah Sasrasoegonda (1910), Zain (1943), Alisjahbana (1963-64), Slametmuljana (1969), dan Koh (1978). Semua karya yang disenaraikan di sini dapat dikatakan merupakan karya peneroka yang diusahakan oleh pengkaji tempatan, namun karya-karya yang muncul kemudian tidak mempunyai ciri khas kajian. 
Pada kesempatan ini perlu ditegaskan bahawa artikel ini tidak merujuk karyakarya lama tersebut secara langsung. Sebaliknya, karya NMM (2009), PKDBI (1996) dan TD (2010) memerincikan hasil kajian yang terdapat dalam karya-karya tempatan tersebut secara tidak langsung kerana latar belakang dan pengalaman pengarangpengarang itu masing-masing. Namun, ternyata karya Boer (1951:58-60) mempunyai ciri tersendiri dalam penggolongan makna akhiran -an $\{-\mathrm{an}\}$ dan berbeza dengan pendekatan yang digunakan oleh ketiga-tiga pengarang tersebut.

Boer (1951) menggolongkan makna akhiran -an \{-an\} kepada tiga golongan besar, iaitu I. objek atau hasil perbuatan (het object of resultaat van een handeling), alat pekerjaan yang digunakan untuk perbuatan (het middle of werking, waarmede de handeling wordt verricht), tempat perbuatan (de plaats van handeling), II. banyak (veelheid), lebih besar (een grotere veelheid), kepelbagaian (een verscheinheid), dan III. keserupaan (gelijkende op, de gelijknis hebbende van), kepunyaan ciri (bezittende, hebbende). Para pembaca yang arif hendaklah meneliti tiga halaman dalam karya ini yang disimpan di perpustakaan besar seperti perpustakaan pusat Universiti Malaya.

Kaedah penggolongan akhiran -an \{-an\} yang dikemukakan dalam Boer (1951) memberikan idea yang bernas kepada artikel ini. Di samping itu, penulis mendapati sesuatu konsep yang baharu, iaitu "himpunan" dalam sebahagian kata terbitan yang tidak disebut oleh beliau. Oleh hal yang demikian, dengan memperkenalkan idea "satuan himpunan" terlebih dahulu, artikel ini secara visual mengembangkan idea perincian makna akhiran -an kepada empat (4) golongan besar, iaitu I. "satuan himpunan", II. "keserupaan", III. "sesuatu yang berkaitan dengan perbuatan", dan IV. "pengaruh bahasa sukuan di Indonesia". Pengaruh bahasa Indonesia terhadap bahasa Melayu di Malaysia tidak dapat dinafikan, dan hal ini dapat dirasai oleh penulis yang telah menjalani kehidupan di rantau nusantara bersama-sama dengan bahasa Melayu dan bahasa Indonesia selama 40 tahun.

\section{DAPATAN DAN PERBINCANGAN}

\section{Analisis (I): Akhiran -an \{-an\} dengan Makna "Satuan Himpunan"}

\subsection{Kata nama tempat berakhiran -an $\{$-an $\}$}

Bahagian ini bermula daripada kata namaan yang diterbitkan bersama akhiran -an \{-an\} yang bermakna "tempat". Jumlah makna akhiran -an $\{$-an\} yang diberikan dalam ketiga-tiga karya NMM, TD, dan PKDBI jauh berbeza, daripada 9 sehingga 31 penggolongan. Kata terbitan berakhiran -an $\{-a n\}$ seperti daratan, lautan, ruangan, 
Jadual 2 Contoh kata nama berakhiran -an $\{-a n\}$

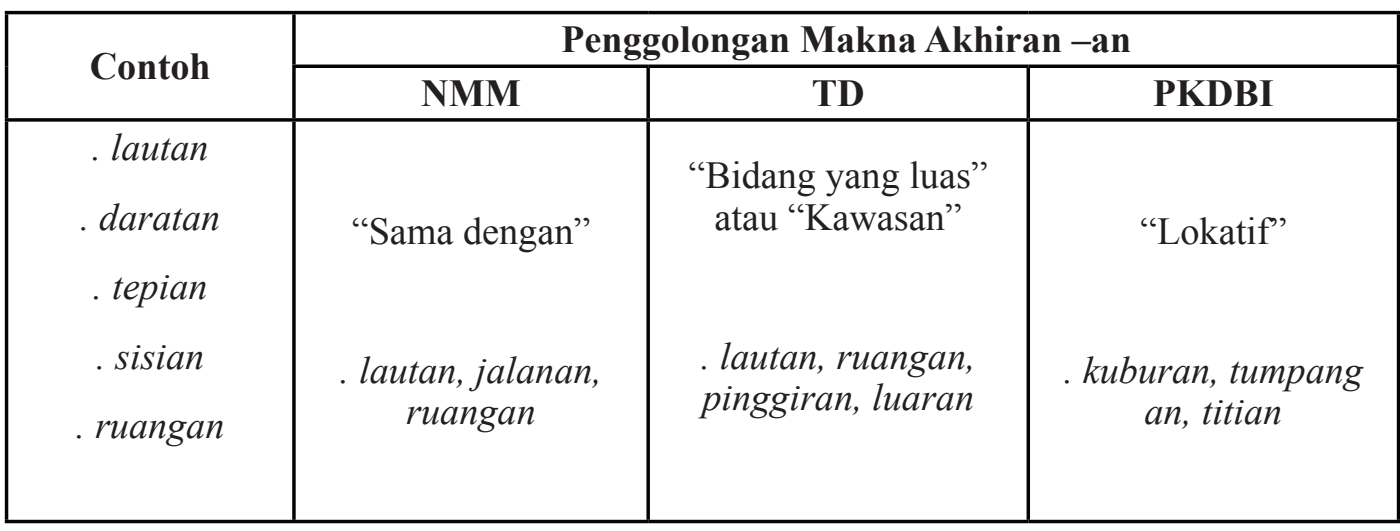

sisian, tepian, misalnya, diberikan tafsiran yang bertentangan antara tiga karya tersebut, seperti yang disenaraikan dalam Jadual 2.

Kata terbitan daratan, misalnya, diberikan tafsiran yang ganjil dalam karya PKDBI kerana makna kata kasar darat dengan makna kata terbitan daratan tidak dibezakan dengan jelas, dengan menggunakan istilah "lokatif" (= tempat). Begitu juga dengan tafsiran NMM, makna kata terbitannya disamakan dengan makna kata dasar.

Bagaimanakah tafsiran yang diberi dalam TD? Cubalah lihat bola bumi. Bumi ini terbentuk daripada dua bahagian, iaitu tanah dan air. Bahagian tanah dan air ini masing-masingnya dapat diganti nama dengan istilah darat dan laut yang memenuhi seluruh bumi.

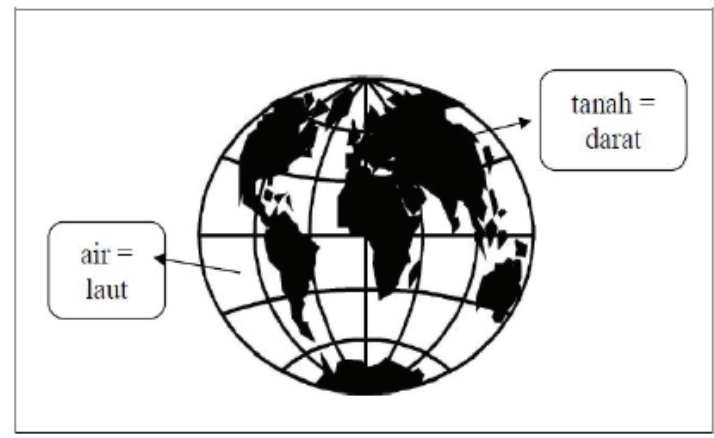

Rajah 1 Bumi terbentuk daripada laut dan darat. 
Apabila tiap-tiap bahagian darat atau laut yang luas diberikan satu nama kawasan yang tertentu, kata terbitan daratan atau lautan digunakan bersama-sama dengan nama kawasan itu, iaitu:

(i) Daratan Asia, Daratan Eropah, Daratan Afrika, dan Daratan Amerika, atau

(ii) Lautan Pasifik, Lautan Hindi, dan Lautan Atlantik.

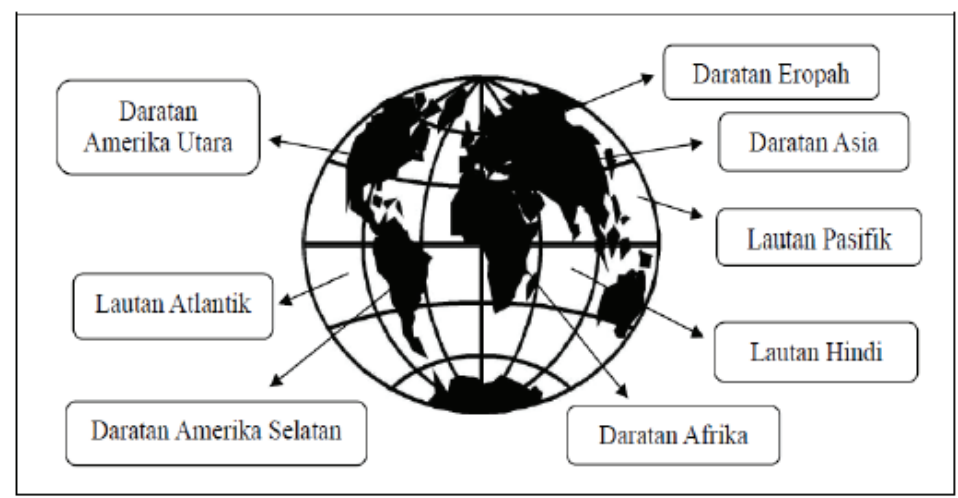

Rajah 2 Satuan daratan dan lautan.

Hal ini bermakna bahawa tiap-tiap daratan atau lautan daripada tanah atau air masing-masing itu digolongkan kepada "sebahagian kelompok" dari segi geografi. Nama tatabahasa juga mencerminkan "satuan himpunan" dalam kata terbitan berakhiran -an $\{$-an\}. Perkara ini tidak bercanggah dengan keterangan geografi: "Ocean: A very large expanse of sea, in particular each of the main areas into which the sea is divided geographically. 'the Atlantic Ocean'." (https://www.lexico.com/ definition/ocean).

Seandainya ruang udara dapat dinyatakan dari segi tatabahasa, kata terbitan *udaraan akan dapat difikirkan, sama seperti daratan dan lautan. Imaginasi ini bermakna kata *udaraan yang sebenarnya tidak wujud juga dapat difikirkan sebagai sebahagian kelompok dari ruang udara.

Rajah 3 ini memperjelas bahawa kata terbitan berakhiran -an $\{-a n\}$ dapat ditafsirkan sebagai membentuk "satuan kelompok (himpunan)" dalam satu "keseluruhan" itu. Kata terbitan ruangan, tepian, sisian, pinggiran juga dapat diterangkan dengan penggolongan yang sedemikian ini. 


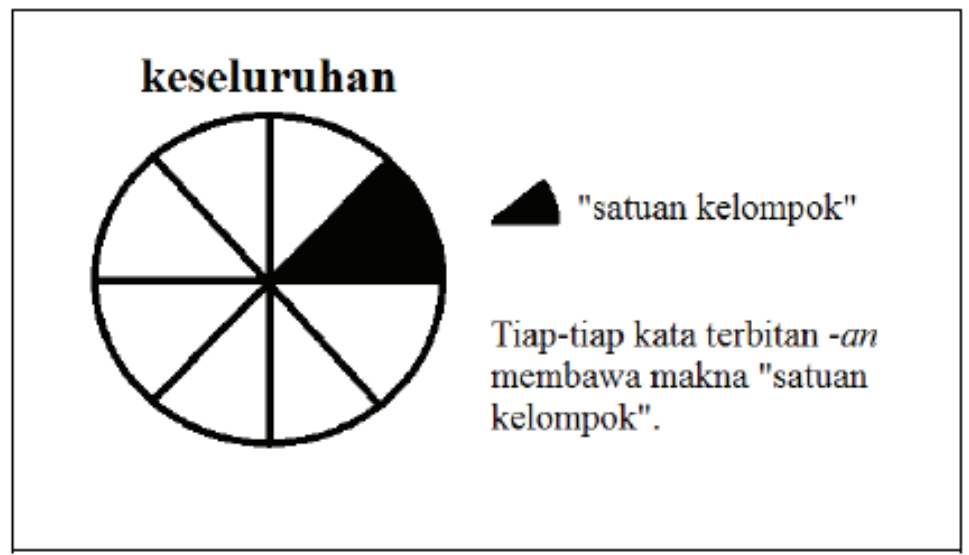

Rajah 3 Gambaran makna satuan kelompok.

\subsection{Kata bilangan berakhiran -an $\{-a n\}$}

Bahagian ini mengaplikasikan idea akhiran -an $\{-a n\}$ "satuan kelompok (himpunan)" kepada kata bilangan terbitan. Contoh dalam Jadual 3 merupakan kata bilangan yang diterbitkan bersama-sama dengan akhiran -an $\{$-an $\}$. Terdapat perbezaan penggolongan makna antara tiga karya NMM, PKDBI, dan TD. Perlu diperhatikan bahawa kata yang disenaraikan dalam tiga karya itu ada yang terkeluar daripada kata bilangan.

Jadual 3 Contoh kata bilangan berakhiran -an

\begin{tabular}{|c|c|c|c|}
\hline \multirow{2}{*}{ Contoh } & \multicolumn{3}{|c|}{ Penggolongan Makna Akhiran -an } \\
\cline { 2 - 4 } . belasan & NMM & TD & PKDBI \\
puluhan & "Pengelompokan" atau & "Banyak" & "Kelompok" \\
ratusan & . satuan, duaan, ribuan, & $\begin{array}{c}\text { parutan, tampungan, } \\
\text { ratusan, durian, } \\
\text { ribuambutan }\end{array}$ & $\begin{array}{c}\text { satuan, ribuan, } \\
\text { picisan, puluhan, } \\
\text { ratusan, dedaunan, } \\
\text { reruntuhan, pepohonan }\end{array}$ \\
\hline
\end{tabular}

Analisis idea "satuan kelompok (himpunan)" bermula dari gambaran bilangan yang bertaburan, seperti yang ditunjukkan pada Rajah 4. Daripada bilangan yang bertaburan ini, bilangan yang berkongsi suatu ciri matematik dapat dihimpunkan mengikut satuan, iaitu "satuan himpunan": 


$$
\begin{array}{cccccccc}
24 & 17 & 90 & 22 & 60 & 13 & 21 & 12 \\
26 & 20 & 14 & 10 & 28 & 18 & 50 & 29 \\
30 & 11 & 16 & 27 & 19 & 25 & 80 & 23 \\
70 & 15 & 40 & & & & &
\end{array}
$$

Rajah 4 Bilangan yang bertaburan.

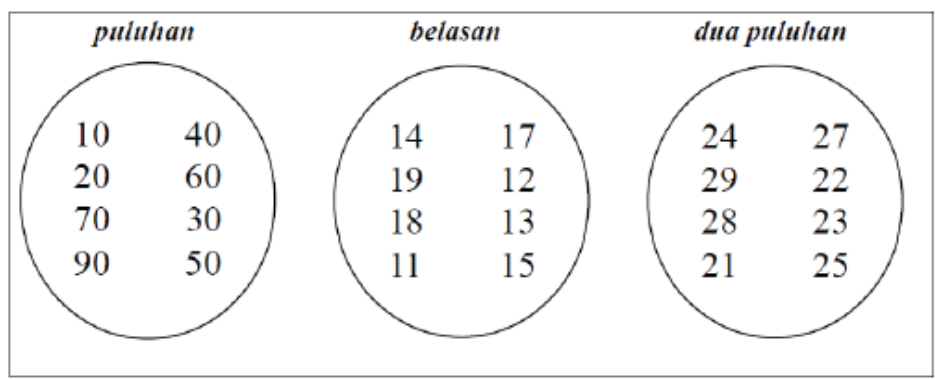

Rajah 5 Satuan himpunan mengikut sifat bilangan.

Satuan himpunan belasan, misalnya, bermula dari bilangan 11 hingga 19 sahaja, iaitu $\{11,12,13,14,15,16,17,18,19\}$. Hal ini dapat dirumuskan seperti belasan $=(10+$ tiap-tiap $n)$. Dengan angkubah $\mathrm{n}$ dimaksudkan tiap-tiap nombor bulat $\{1,2,3,4,5,6,7,8,9\}$.

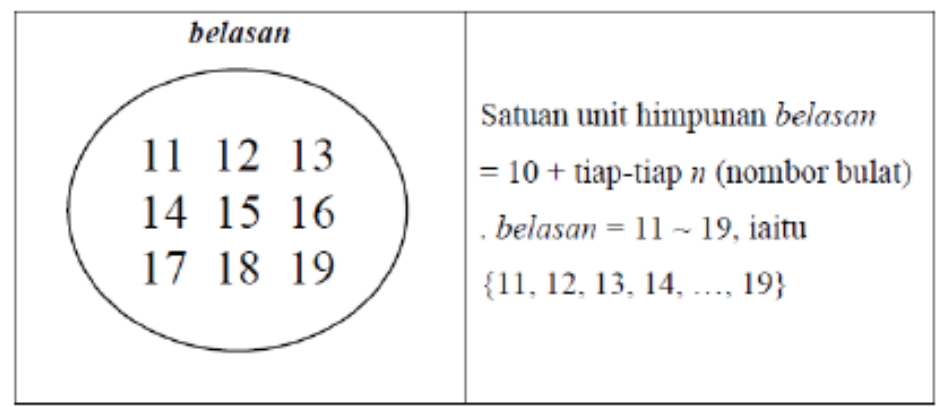

Rajah 6 Satuan himpunan belasan.

Begitu juga bilangan puluhan seperti 20-an, 30-an dan seterusnya dapat dirumuskan sebagai $(2 \times 10+$ tiap-tiap $n),(3 \times 10+$ tiap-tiap $n)$ dan sebagainya. 
Bilangan ratusan, ribuan dan seterusnya juga dapat dirumuskan dengan cara yang serupa. Hal ini bermakna bahawa akhiran -an $\{-a n\}$ ini dapat membentuk makna "satuan himpunan". Daripada analisis tersebut dapat dikatakan bahawa tafsiran TD "banyak" itu tidak mencerminkan makna akhiran -an $\{$-an $\}$ dengan jelas dan tepat.

\subsection{Kata nama sukatan masa berakhiran -an $\{-$ an $\}$}

Bahagian ini merupakan perkembangan perbincangan bahagian 1.1. Rajah 7 menaburkan kata nama sukatan masa dalam satu keseluruhan masa.

hari Isnin Minggu 2 bulan Mac hari Khamis bulan April hari Jumaat Minggu 3

bulan Januari hari Ahad Minggu 1

bulan Februari hari Sabtu Minggu 4 hari Selasa hari Rabu

Rajah 7 Kata nama sukatan masa yang bertaburan.

Dalam kata nama sukatan masa yang bertaburan ini, kata nama yang berkongsi suatu ciri yang bersama dapat dihimpunkan mengikut satuan:

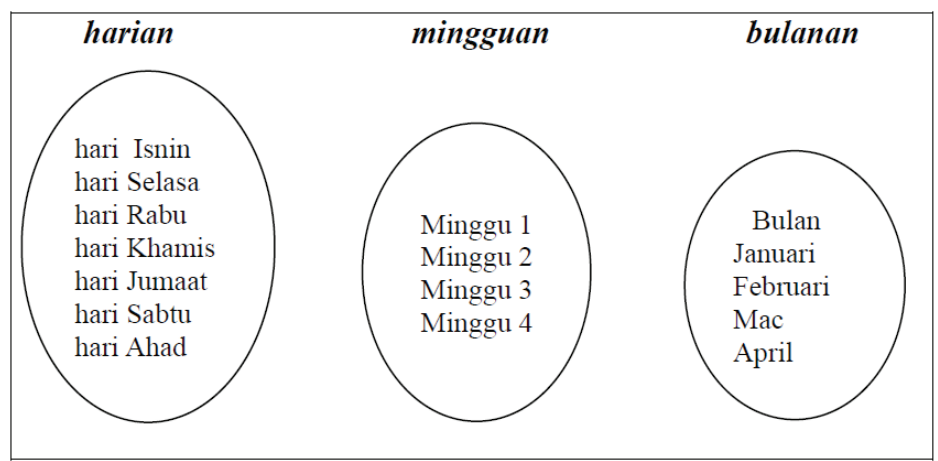

Rajah 8 Sukatan masa dalam satuan himpunan masa.

Tiap-tiap himpunan masa ini dapat diungkapkan dengan istilah harian, mingguan, dan bulanan yang diterbitkan bersama-sama dengan akhiran -an \{-an\} "satuan himpunan" yang membawa makna perulangan "tiap-tiap". 
Dalam hal ini terdapat satu lagi kata terbitan berawalan be(R)- yang serupa maknanya dengan akhiran -an $\{-a n\}$ : berhari-hari, berminggu-minggu, dan berbulan-bulan, dan bertahun-tahun, seperti diterangkan dalam Carian Umum DBP Malaysia, iaitu kata terbitan tahunan membawa makna "sudah bertahun-tahun" dalam bahasa percakapan.

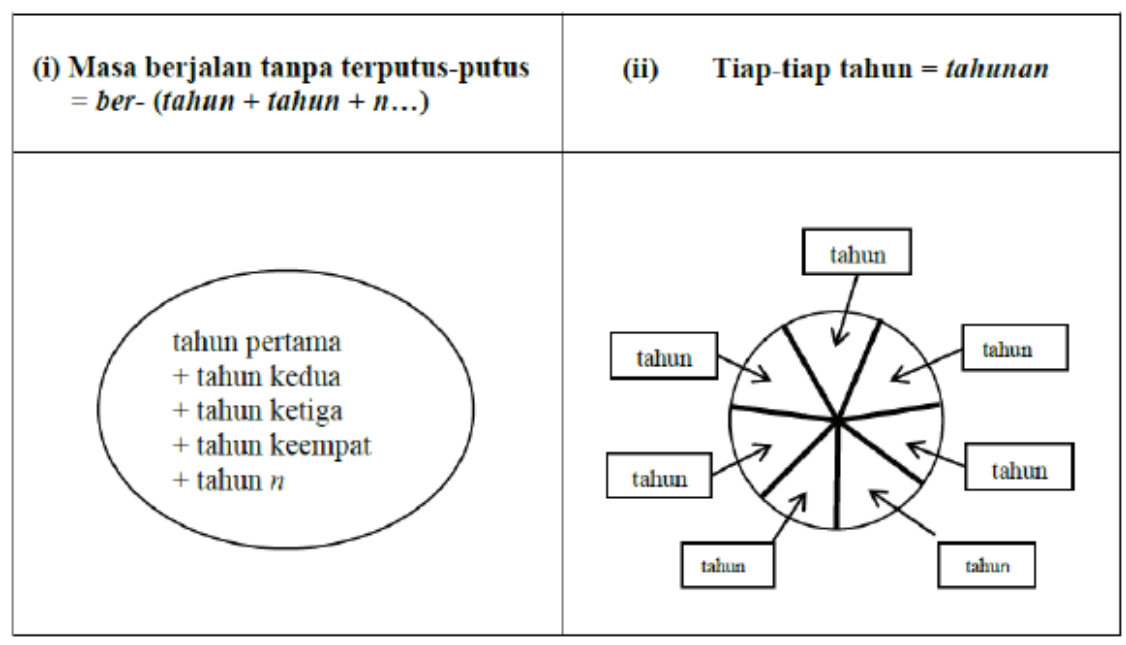

Rajah 9 Satuan himpunan masa bertahun-tahun.

Perbezaan makna antara kata terbitan berawalan be(R)- dengan kata terbitan berakhiran -an $\{-a n\}$ dapat dilakarkan pada Rajah 9 dari segi tatabahasa. Kata terbitan bertahun-tahun merujuk (i) himpunan masa: "masa yang berjalan dengan terus-menerus" atau "masa yang berjalan dengan tidak terputus-putus", manakala kata terbitan tahunan pula merujuk (ii) himpunan masa: "tiap-tiap satuan masa dalam sesuatu himpunan masa" jika perbincangan dalam artikel ini dapat

Jadual 4 Contoh kata nama sukatan lain.

\begin{tabular}{|c|c|}
\hline . bermeter-meter & . meteran $=$ tiap-tiap meter \\
\hline . berkilo-kilo & . kiloan $=$ tiap-tiap kilo \\
\hline . berlusin-lusin & . lusinan $=$ tiap-tiap lusin \\
\hline . berbatu-batu & . batuan $=$ tiap-tiap batu \\
\hline . berkodi-kodi & . kodian $=$ tiap-tiap kodi \\
\hline
\end{tabular}


diterapkan. Istilah bahasa Indonesia jam-jaman dapat diterangkan dengan tafsiran ini: mobil sewaan jam-jaman (= kereta yang disewa dengan bayaran tiap-tiap jam).

Dalam pada itu, sata nama sukatan yang menyatakan "panjang benda", "berat benda", "jumlah benda", dan "jarak perjalanan" juga dapat membentuk kata terbitan berakhiran -an $\{$-an $\}$. Lihat Jadual 4.

\subsection{Kata nama jenis berakhiran -an $\{-a n\}$}

Bahagian ini merupakan sambungan perbincangan bahagian 1.3. Rajah 10 menaburkan kata nama jenis daging dan sayur. Kata nama jenis yang diterbitkan bersama akhiran -an \{-an\} sudah lama ditafsirkan membawa makna "kepelbagaian". Tafsiran ini dapat diperjelas dengan idea "satuan himpunan" (lihat Rajah 11).

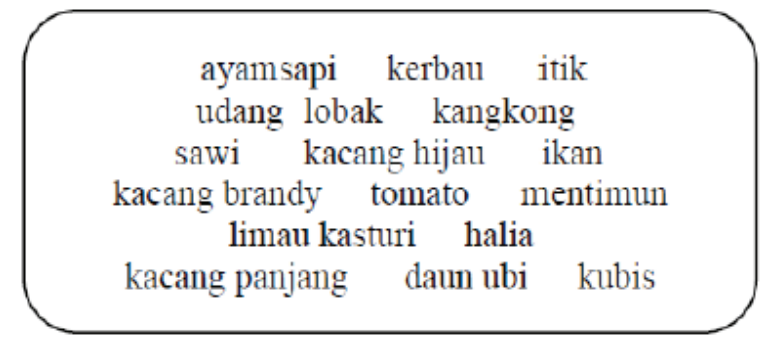

Rajah 10 Taburan kata nama jenis makanan.

Dalam jenis makanan yang bertaburan ini, kata nama jenis yang berkongsi suatu ciri bersama dapat dihimpunkan dalam Rajah 11, mengikut satuan himpunan:

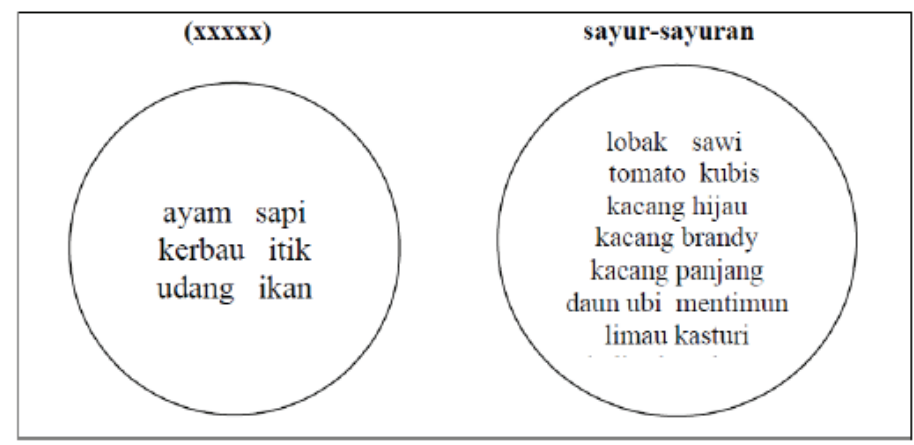

Rajah 11 Kata nama jenis makanan dalam satuan himpunan. 
Sifat kepelbagaian itu juga sepatutnya diertikan dalam idea penggolongan "satuan himpunan" seperti yang ditunjukkan dalam Rajah 12 sahaja.

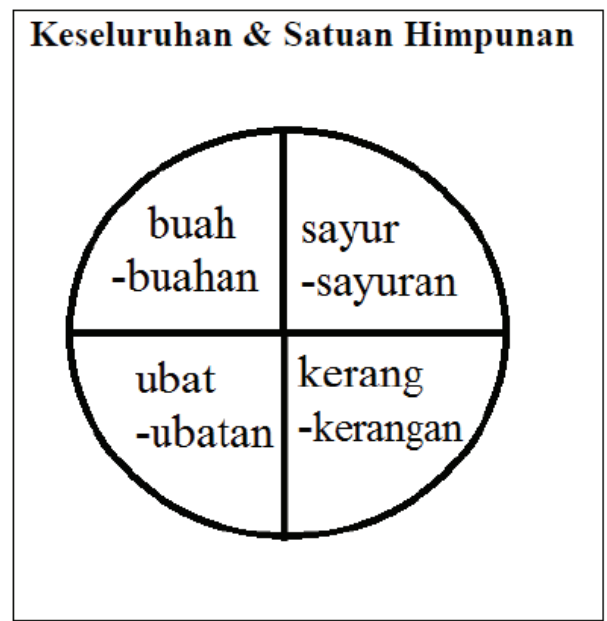

Rajah 12 Keseluruhan "makanan” dan satuan himpunan.

Ciri morfologinya yang satu lagi dalam golongan ini dapat dilihat dalam penggandaan kata dasar yang diberi akhiran -an $\{-a n\}$ : buah-buahan, kacangkacangan, kerang-kerangan, sayur-sayuran, tumbuh-tumbuhan, pohon-pohonan, ubat-ubatan, melainkan kata *daging-dagingan yang tidak wujud dalam bahasa Melayu.

\section{Analisis (II): Akhiran -an \{-an\} dengan Makna "Keserupaan" atau "Perhinggaan"}

Bahagian ini mengemukakan satu lagi penggolongan makna akhiran -an $\{$-an\}. Dua karya NMM dan PKDBI memberikan satu kategori makna, manakala TD tidak menyediakan apa-apa makna bagi kata terbitan berakhiran ini, seperti dalam Jadual 5. Kata terbitan berakhiran -an $\{-a n\}$ dalam analisis (II) ini sebaik-baiknya dibahagikan kepada dua kumpulan yang saling melengkapi, iaitu (i) "keserupaan bentuk atau sifat" dalam bentuk kata nama atau kata adjektif; dan (ii) "keserupaan perbuatan" dalam bentuk kata kerja atau kata adverba. 
Jadual 5 Contoh kata terbitan berakhiran -an $\{-a n\}$.

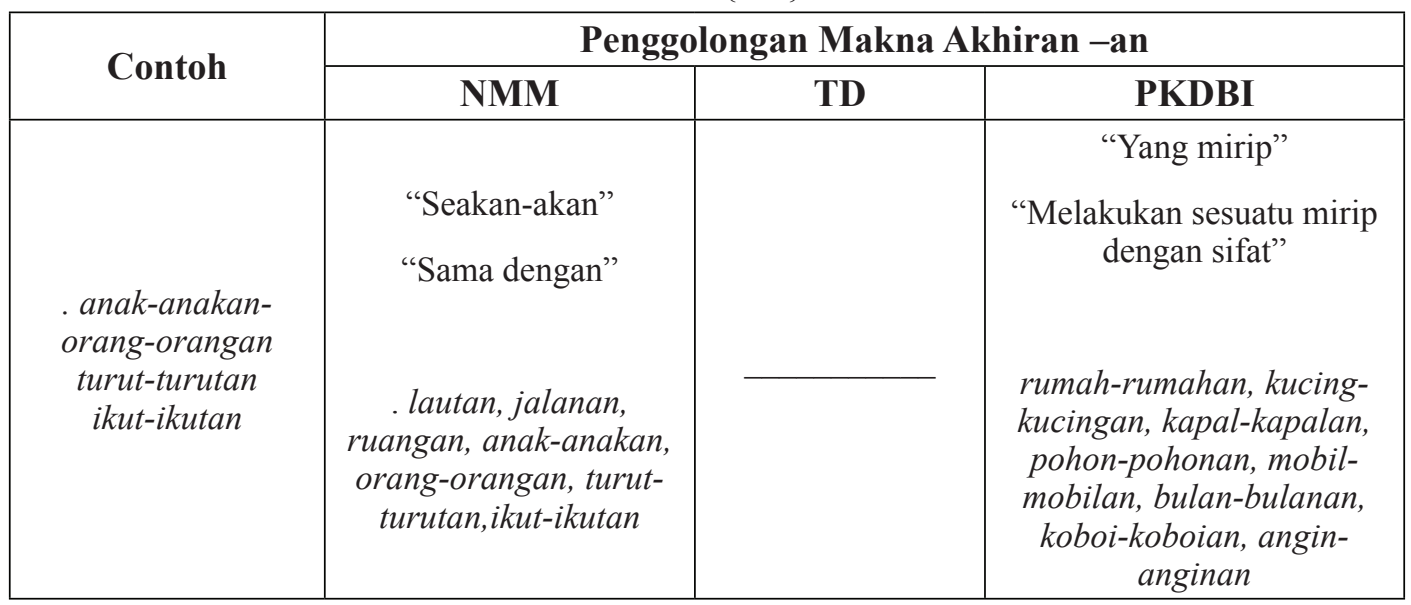

\subsection{Kata nama atau kata adjektif berakhiran -an $\{-a n\}$}

Kata nama terbitan dalam golongan ini membawa makna "keserupaan bentuk atau sifat" yang mempunyai sesuatu ciri yang tertentu. Contoh yang sering disebut secara tradisional ialah buah durian ( $<$ duri) dan buah rambutan $(<$ rambut $)$, dan talian $(<$ tali). Namun begitu, kata ini barangkali sudah tidak dianggap sebagai kata terbitan lagi.

Makna "keserupaan bentuk" ini dapat dilihat dengan lebih jelas dalam kata nama terbitan berakhiran -an $\{$-an\} seperti anak-anakan (patung atau boneka yang menyerupai anak), mobil-mobilan (barang mainan yang menyerupai mobil/kereta), dan orang-orangan (patung yang menyerupai orang yang dipacakkan di sawah untuk menakutkan burung) yang kesemuanya dihasilkan dengan menggandakan kata dasarnya. Imaginasinya dapat dilakarkan dengan benda-benda yang bertindih. Bahasa Indonesia sangat kaya dengan contoh yang seperti ini. Imaginasinya dilakarkan dalam Rajah 13.

Makna "keserupaan" ini menghasilkan kata terbitan yang merangkap fungsi kata adjektif, seperti kampungan (yang terbelakang, tidak tahu terdidik), murahan (yang tidak mempunyai mutu), dan pasaran (yang terdapat di merata-rata tempat) dalam bahasa percakapan di Indonesia pada tahun 1970-an.

Berdasarkan pemerhatian, kata kampungan, murahan dan pasaran dalam makna tersebut jarang digunakan dalam percakapan di Malaysia pada awal tahun 1980. Terdapat kata terbitan kampungan dan pasaran dalam Kamus Dewan (1970). Akan tetapi, makna kampungan tersebut tidak dinyatakan, manakala kata pasaran dimuatkan bersama maknanya (kualiti kurang baik [barang dagangan]) tetapi 


\begin{tabular}{|l|l|l|}
\hline Contoh & orang & orang-orangan \\
\hline Tlustrasi & & $\begin{array}{l}\text { Nampaknya seperti orang tetapi bukan } \\
\text { orang. Patung (= orang-orangan }) \text { ini } \\
\text { menyerupai orang. Makna "keserupaan" } \\
\text { adalah serupa dengan ungkapan "seolah- } \\
\text { olah" atau "seakan-akan". }\end{array}$ \\
\hline Penjelasan & Bentuk badan manusia & \\
\hline
\end{tabular}

Rajah 13 Makna "keserupaan bentuk" pada kata orang-orangan.

contoh ayatnya tidak diberikan. Pihak Indonesia juga baru memperkenalkan kata terbitan kampungan, murahan dan pasaran dengan makna tersebut dalam Kamus Besar Bahasa Indonesia (KBBI) pada tahun 1988. Padahal, kata-kata ini sudah lama digunakan sehari-hari di Indonesia pada tahun 1970-an. Buktinya dapat disaksikan dalam Kamus Umum Indonesia-Inggeris oleh Wojowasito (1976).

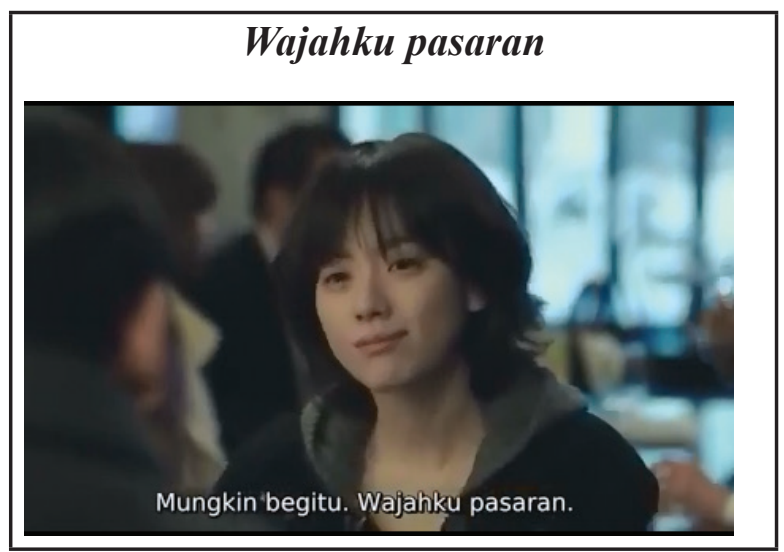

Rajah 14 Filem Cold Eyes (2013) diberi sari kata dalam bahasa Indonesia.

Kata terbitan seperti kata gunaan, fungsian, tempatan, dan terapan yang semakin umum digunakan di Malaysia (kata-kata ini tidak terdapat di Indonesia) berfungsi 
sebagai kata adjektif, tetapi sukar untuk dikaitkan dengan makna "keserupaan bentuk atau sifat". Hal ini dibincangkan di bahagian Analisis (III).

Seperkara lagi, kata terbitan lautan telah disebut dalam Analisis (I), bahagian 1.1 yang membincangkan "satuan kolompok". Kata ini, misalnya, juga mempunyai makna kiasan yang dapat digolongkan ke dalam golongan makna "seakan-akan":

[1] Jumlah semut di situ lautan banyaknya.

Kata terbitan lautan dalam ayat [1] bukan merujuk satu kawasan geografi tetapi secara kiasan menggambarkan sekumpulan semut yang berkumpul di satu tempat. Hal ini perlu diperjelas melalui langkah yang berikut:

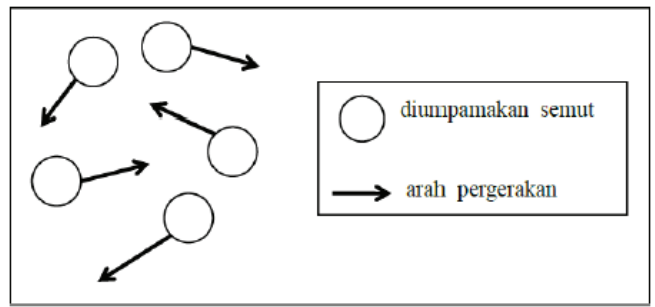

Rajah 15 Pergerakan semut yang tiada hala tuju.

Dalam Rajah 15 dimaksudkan bahawa pergerakan tiap-tiap ekor semut merayap ke arah masing-masing dengan tidak menentu. Maksudnya, tidak terdapat himpunan. Namun begitu, jika diberi satu pusat tumpuan seperti dalam Rajah 16, semua semut akan bergerak menuju ke arah pusat itu dan seakan-akan membentuk satu himpunan semut. Himpunan inilah digambarkan sebagai lautan semut (= kawasan yang menyerupai himpunan semut yang amat banyak). Contoh lain seperti lautan angin, lautan api, lautan tanah juga dapat diimaginasikan dengan cara yang sedemikian.

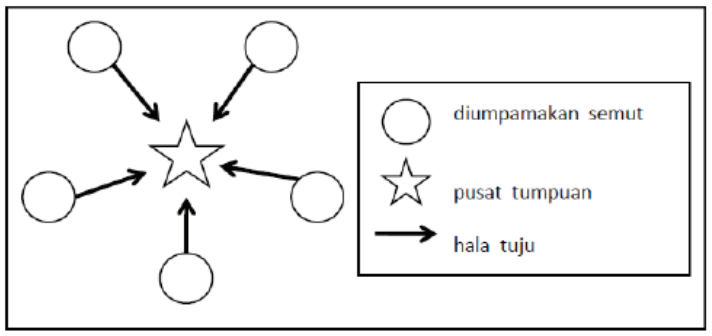

Rajah 16 Pergerakan semut yang menuju ke satu pusat. 


\subsection{Kata adverba atau kata kerja berakhiran -an}

Kata terbitan yang tergolong dalam golongan ini membawa makna "gaya perbuatan yang menyerupai sesuatu". Maksudnya ialah sesuatu perbuatan dilakukan "seolaholah", dan sesuatu perbuatan itu mendekati makna yang terkandung dalam kata dasarnya, iaitu "seakan-akan tiada perhinggaan" atau "seakan-akan tiada penghujung":

tidur-tiduran $=$ berbaring-baring tetapi tidak tidur (untuk melepaskan lelah dsb).

besar-besaran = megah, meriah; gencar, habis-habisan .

ikut-ikutan = mengikut sahaja (fikiran, perbuatan, dsb) orang lain (tanpa kesedaran atau keinsafan).

mati-matian = pura-pura mati; tidak benar-benar mati; dng bersungguh-sungguh;

bekerja dng segenap tenaga.

Rajah 17 mengimaginasikan sesuatu perbuatan yang bermula dari sebelah kiri (tanda •) itu menuju ke arah sesuatu objek di sebelah kanan tetapi tidak mencapai makna yang dibawa oleh kata dasar. Maksudnya, gaya perbuatan itu terjadi melalui "satu perjalanan yang seolah-olah tidak berhingga": habis-habisan, kecil-kecilan, dan sungguh-sungguhan.

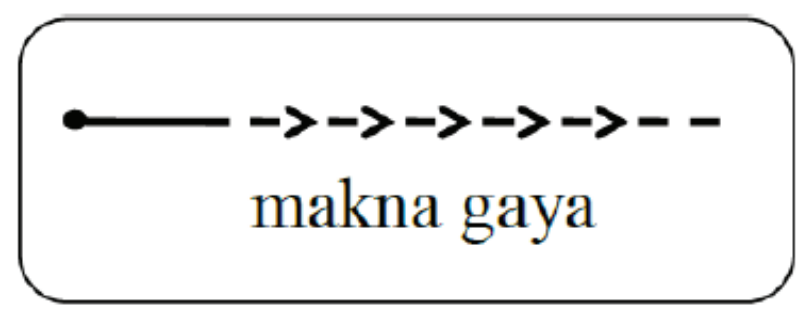

Rajah 17 Proses perbuatan "seolah-olah".

Karya TD tidak memberikan contoh bagi makna "seolah-olah atau seakanakan”, dan PKDBI pula mencampurkan pelbagai makna akhiran -an \{-an\} yang digunakan dalam bahasa daerah (bahasa suku bangsa) di bawah kategori ini (lihat Jadual 6).

Sementara itu, kata terbitan seperti mati-matian dan habis-habisan yang dihasilkan dengan menggandakan kata dasarnya adakalanya dianalisis sebagai 
Jadual 6 Contoh kata terbitan berakhiran -an $\{-a n\}$.

\begin{tabular}{|c|c|c|c|}
\hline \multirow{2}{*}{ Contoh } & \multicolumn{3}{|c|}{ Penggolongan Makna Akhiran -an } \\
\hline & NMM & TD & PKDBI \\
\hline & & & "lebih" \\
\hline & & & “dalam keadaan” \\
\hline & & & "sambil lalu” atau \\
\hline . habis-habisan & "adverba perhinggaan" & & "tidak bersungguh" \\
\hline . besar-besaran & "adverba gaya" & & "sungguh-sungguh" \\
\hline . kecil-kecilan & & & “ketidakpastian" \\
\hline . terang-terangan & habis-habisan, besar- & & \\
\hline $\begin{array}{l}\text {. sungguh-sungguhan } \\
\text {. mudah-mudahan }\end{array}$ & & & $\begin{array}{c}\text { pintaran, cantikan, } \\
\text { kudisan, tidur-tiduran, } \\
\text { ogah-ogahan, segan- } \\
\text { seganan, dua-duaan, } \\
\text { acak-acakan }\end{array}$ \\
\hline
\end{tabular}

menggunakan apitan be(R)-/-an seperti bermati-matian dan berhabis-habisan. Padahal, NMM memberikan contoh sehari-harian $(<$ sehari-hari $<$ hari) dan semalam-malaman $(<$ semalam-malam $<$ malam) yang kedua-duanya dianalisis sebagai diberikan akhiran -an sahaja. Maksudnya, NMM tidak mengakui kewujudan apitan se-/-an yang membawa makna "perhinggaan". Hal yang demikan terdapat dalam banyak karya tatabahasa yang diterbitkan di negara-negara rantau Melayu sejak zaman dahulu. Masalah ini perlu dipersoalkan pada kesempatan lain.

\section{Analisis (III): Akhiran -an \{-an\} dengan Makna "Proses Perbuatan"}

Kata terbitan berakhiran -an yang tergolong dalam golongan ini dapat diperjelas dengan dikaitkan dengan makna "proses perbuatan" secara kasar. Walaupun ketigatiga karya NMM, TD, dan PKDBI memberikan makna yang berbeza-beza bagi sekumpulan kata terbitan ini seperti yang ditunjukkan dalam Jadual 7, tetapi kata terbitan golongan ini dapat dikaitkan secara imaginatif dengan makna "sesuatu yang berkaitan dengan proses perbuatan" itu.

Kata terbitan dalam golongan ini dapat digambarkan dengan dikaitkan dengan garisan "proses perbuatan” seperti dalam Rajah 18. 
Jadual 7 Contoh kata terbitan berakhiran -an.

\begin{tabular}{|c|c|c|c|}
\hline \multirow{2}{*}{ Contoh } & \multicolumn{3}{|c|}{ Penggolongan Makna Akhiran -an } \\
\hline & NMM & TD & PKDBI \\
\hline $\begin{array}{c}. \text { makanan } \\
\text {. jagaan } \\
\text { peliharaan } \\
\text {. latihan }\end{array}$ & $\begin{array}{l}\text { "benda atau orang atau } \\
\text { hal yang dikenakan } \\
\text { perbuatan" } \\
\text { "benda yang dihasilkan } \\
\text { daripada perbuatan" } \\
\text { "orang yang melakukan } \\
\text { perbuatan" } \\
\text { "Alat untuk membuat } \\
\text { sesuatu" } \\
\text { minuman, tulisan, } \\
\text { buatan, binaan, jahitan, } \\
\text { timbalan, saringan, } \\
\text { tapisan }\end{array}$ & $\begin{array}{c}\text { "kerja atau perkara } \\
\text { atau benda atau hasil } \\
\text { daripada perbuatan" } \\
\text { "alat" } \\
\text { "orang atau haiwan } \\
\text { atau perkara atau } \\
\text { benda menjadi } \\
\text { penderita kerja" } \\
\text { "Tempat melakukan } \\
\text { sesuatu" } \\
\\
\text { kritikan, bekalan, } \\
\text { lukisan, keluaran, } \\
\text { kukuran, acuan, } \\
\text { suruhan, tawanan, } \\
\text { jemputan, hamparan }\end{array}$ & $\begin{array}{c}\text { "hasil" } \\
\text { "apa yang di ..." } \\
\text { "alat untuk ..." } \\
\text { "yang ditempatkan di ..." } \\
\text { "Kegiatan yang } \\
\text { bersangkutan dengan" } \\
\text { "Berbalasan" } \\
\text { garisan, akhiran, awalan, } \\
\text { bawahan, Natalan, } \\
\text { syukuran, cubit-cubitan }\end{array}$ \\
\hline
\end{tabular}

Rajah 18 menggambarkan suatu proses perbuatan dengan tanda panah. Tanda (•) yang di sebelah kiri menandakan permulaan perbuatan, manakala tanda panah $(\rightarrow$ ) yang menuju ke arah kanan menandakan perjalanan perbuatan itu. Proses perbuatan dengan kata terbitan berakhiran -an $\{-a n\}$ itu tentulah memerlukan konsep yang berikut:

(i) Konsep "alat perbuatan" ialah sesuatu yang digunakan untuk mengerjakan sesuatu: timbangan, gantungan.

(ii) Konsep "cara perbuatan" ialah gaya perbuatan: buatan, jahitan.

(iii) Konsep "tempat perbuatan" ialah lokasi berlakunya sesuatu perbuatan: laluan, tumpangan, pangkalan.

(iv) Konsep "waktu perbuatan" ialah masa sesuatu perbuatan berlaku: Natalan (di Indonesia).

(v) Konsep "hasil atau sasaran perbuatan" ialah sesuatu yang dihasilkan atau sesuatu yang dicapai: terjemahan, alasan, minuman. 
Maksudnya, proses perbuatan ini melibatkan salah satu konsep tersebut untuk menghasilkan sesuatu atau mencapai sasaran, seperti yang disimpulkan dalam Rajah 18.

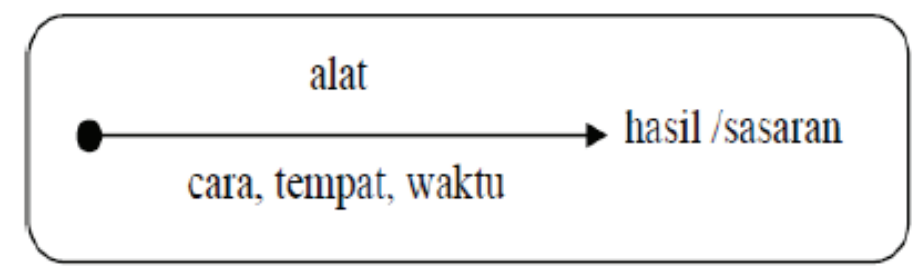

Rajah 18 Proses perbuatan.

Ketiga-tiga karya NMM, TD, dan PKDBI memang menyenaraikan makna kata terbitan secara terperinci tetapi konsep "proses perbuatan" sama sekali tidak diberi perhatian. Oleh sebab itu, Jadual 8 menyusun semula perincian makna kata terbitan berakhiran -an dalam golongan ini.

Jadual 8 Perincian makna dalam proses perbuatan.

\begin{tabular}{|c|c|c|c|c|}
\hline Alat & Tempat & Cara & Waktu & $\begin{array}{c}\text { Hasil atau } \\
\text { Sasaran }\end{array}$ \\
\hline gantungan & tumpangan & buatan & Natalan & tulisan \\
\hline kukusan & kuburan & jahitan & (di Indonesia) & karangan \\
\hline usungan & pintasan & & & .terjemahan \\
\hline ayunan & belokan & & & makanan \\
\hline buaian & .pusingan & & & minuman \\
\hline pegangan & larian & & & . cucian \\
\hline timbangan & laluan & & & lepasan \\
\hline
\end{tabular}

\section{Analisis (IV): Pengaruh Bahasa Sukuan terhadap Makna Akhiran -an}

Terdapat kata terbitan berakhiran -an \{-an\} yang tidak digunakan dalam bahasa Melayu standard di Malaysia. Sebilangan kata terbitan tersebut merupakan hasil pengaruh bahasa Jawa atau bahasa Sunda dalam sejarah perkembangan bahasa Indonesia. Satu contoh ditunjukkan dalam Rajah 19. 


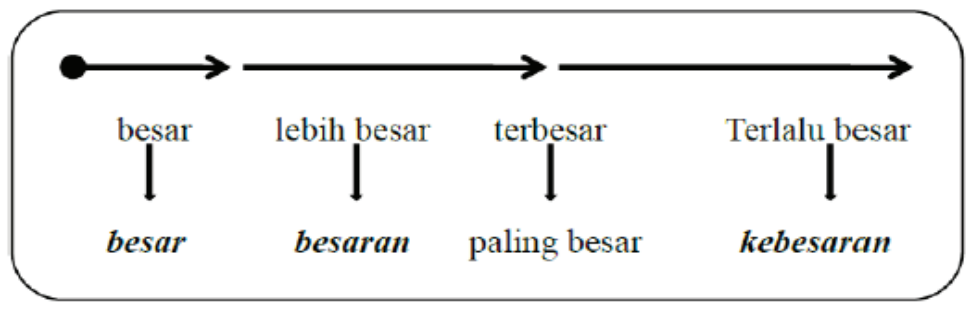

Rajah 19 Makna akhiran -an $\{-a n\}$ dan pengaruh bahasa Jawa.

Bermula dari kata dasar besar, kata terbitan besaran (akhiran -an) membawa makna "komparatif", iaitu lebih besar dalam bahasa percakapan Indonesia. Begitu juga, kata terbitan kebesaran (apitan ke-/-an) membawa makna "keterlaluan", iaitu terlalu besar. Kesemua akhiran -an $\{-$ an $\}$ ini, sudah umum diketahui dalam kalangan pengkaji bahasa di Indonesia, merupakan hasil bahasa pengaruh Jawa atau Sunda. Kata adverba paling sendiri merupakan kata pinjaman daripada bahasa Jawa.

Satu lagi contoh dapat dilihat dalam kata adjektif atau kata nama terbitan seperti ubanan, ingusan, dan kudisan yang diberi akhiran -an $\{-a n\}$ yang membawa makna yang sama dengan awalan be(R)- "memiliki, dilengkapi". Kata-kata yang tergolong dalam kategori ini diperkenalkan di subbahagian 2.1. Makna ini juga sudah lama terserap daripada bahasa Sunda kepada bahasa Indonesia dalam sejarah perkembangan Indonesia.

Ragam kerja medium (middle voice) dapat diwujudkan dalam bentuk kata kerja atau kata adverba terbitan seperti cepatan, duluan, belakangan yang juga terpengaruh oleh bahasa sukuan seperti bahasa Jawa atau bahasa Sunda di Indonesia.

\section{KESIMPULAN}

Akhiran -an $\{-a n\}$ dianggap sebagai imbuhan yang paling mudah dipelajari dari segi perubahan bentuk morfologi bahasa Melayu kerana akhiran ini mempunyai satu morf /-an/ sahaja. Dari segi makna pula, akhiran -an $\{-a n\}$ diperincikan secara logik oleh pengarang NMM (2009), PKDBI (1996) dan TD (2010) kepada 9 hingga 31 golongan yang berbeza-beza. Namun begitu, logik yang dikembangkan dalam tiga buah karya tersebut tidak meringankan beban pelajar dalam pembelajaran akhiran ini.

Dalam hal ini, karya Boer (1951: 58-60) menghasilkan penggolongan tersendiri dalam karya tatabahasa bahasa Melayu, dan penulis mendapati konsep "himpunan" 
dalam sebahagian kata terbitan berakhiran -an $\{-a n\}$ tidak disebut oleh beliau. Oleh hal yang demikian, penulis telah menyusun semula definisi makna akhiran -an \{-an\} secara logik dan menggolongkannya kepada empat (4) golongan yang besar, iaitu I. "satuan himpunan", II. "keserupaan", III. "sesuatu yang berkaitan dengan proses perbuatan", dan IV. "pengaruh bahasa sukuan di Indonesia". Definisi makna ini mengambil kira unsur dan pengaruh bahasa percakapan Indonesia terhadap bahasa Melayu standard yang mungkin tidak disedari oleh penutur jati di Malaysia dan di Negara Brunei Darussalam.

\section{RUJUKAN}

Abdullah Hassan. (1986). Penerbitan kata dalam bahasa Malaysia. Fajar Bakti.

Alisjahbana, Sutan Takdir. (1963-64). Tatabahasa baru bahasa Melayu/Indonesia (I) (Chetakan pertama di Malaysia). Zaman Baru.

Asmah Haji Omar. (2009). Nahu Melayu mutakhir. Dewan Bahasa dan Pustaka.

Badan Pengembangan dan Pembinaan Bahasa, (1989). Kamus Besar Bahasa Indonesia. Balai Pustaka.

Badudu \& Sutan Mohammad Zain. (1994). Kamus umum bahasa Indonesia. Pustaka Sinar Harapan.

Boer, D. W. N. de. (1951). Beknopte Indonesische grammatica van klassiek naar modern Maleis. E.J. Brill.

Chung, Siaw-Fong. 2011. Uses of ter-in Malay: A corpus-based study. Journal of Pragmatics, 43, 799 - 813. Diakses daripada https://www.sciencedirect.com/journal/journal-ofpragmatics/vol/43. (1 Januari 2019).

Dewan Bahasa dan Pustaka. (2021). "tahunan", dlm. laman web Carian Umum. Dewan Bahasa dan Pustaka.

Harimurti Kridalaksana. (1996). Pembentukan kata dalam Bahasa Indonesia (Edisi ke-2). Penerbit PT Gramedia Pustaka Utama.

Hollander, J.J. de. (1882). Handleiding bij de beoefening der Maleische Taal en Letterkunde (5de druk). Broese \& Comp.

Klinkert, H. C. (1898). Spraakleer van het Maleisch (2de uitgave). E.J. Brill.

Koh Boh Boon. (1978). The teaching of Malay affixes. Penerbit Fajar Bakti.

Lee Yu-jin (penerbit). (2013). Filem cold eyes. Sari kata bahasa Indonesia. Sundream Motion Pictures. 
Nik Safiah Karim, Farid Onn, Hashim Musa, dan Abdul Hamid Mahmood. (2010). Tatabahasa Dewan (Edisi ke-3). Dewan Bahasa dan Pustaka.

Ophuijsen, Ch. A. van, (1915). Malesiche Spraakkunst (2de druk). S.C. van Doesburgh.

Sasrasoegonda, K. (1986). Kitabjang menjatakan djalannja Bahasa Melajoe. 1910 (Dicetak semula). Balai Pustaka.

Sato, Hirobumi@ Rahmat. (2007). Analogi dalam tafsiran ungkapan bahasa Melayu: matahari sepenggalah tingginya. Jurnal Bahasa, 7(1), 121-141. Kuala Lumpur: Dewan Bahasa dan Pustaka.

Sato, Hirobumi@ Rahmat. (2020). Lakaran serentetan makna awalan me(N)- dan te(R)dalam Bahasa Melayu. Jurnal Bahasa, 39, 94-114. Bandar Seri Begawan: Dewan Bahasa dan Pustaka.

Sidang editor Lexico. (2021). Ocean. Lexico powered by Oxford. https://www.lexico.com/ definition/ocean. (10/12/2021).

Slametmuljana. (1969). Kaidah Bahasa Indonesia. Nusa Indah.

Spat, C. (1900). Maleische Taal. Koninklijke Militaire Academie.

Spat, C. (1931). Maleische Taal (5de druk). Koninklijke Militaire Academie.

Tendeloo, H. J. E. (1901). Maleische grammatica (eerste deel). E.J. Brill.

Wijk, D. Gerth van. (1893). Spraakleer der Maleische taal (2de druk). G. Kolff \& Co.

Winstedt, R. O. (1913). Malay grammar. Clarendon Press.

Wojowasito, S. (1976). Kamus umum Indonesia-Inggeris. Penerbit C.V. Pengarang.

Wouk, Fay. 1980. "The ter- Prefix in Indonesian: A Semantic Analysis", in Austronesian Studies: Papers from the Second Eastern Conference on Austronesian Languages, pp. 81-87.

Zain, Sutan Muhammad. (1943). Djalan bahasa Indonesia. Ksatria.

Zain, Sutan Muhammad. (1954). Kamus Moderen Bahasa Indonesia. Penerbit Grafika. 